\title{
Speckle-Type POZ Protein
}

National Cancer Institute

\section{Source}

National Cancer Institute. Speckle-Type POZ Protein. NCI Thesaurus. Code C102538.

Speckle-type POZ protein (374 aa, $42 \mathrm{kDa}$ ) is encoded by the human SPOP gene. This protein may be involved in the modulation of transcription and the ubiquitination of proteins. 